\title{
Оценка чувствительности полевого изолята кокцидий к химически синтезированным и комплексным антикокцидийным препаратам
}

Бирюков И.М., научный сотрудник отдела паразитологии

Симонова Е.А., младший научный сотрудник отдела паразитологии

Всероссийский научно-исследовательский ветеринарной институт птицеводства (ВНИВИП) - филиал ФНЦ «ВНИТИП» РАН

\begin{abstract}
Аннотация: Проведена оценка чувствительности полевого изолята кокцидий к антикокцидийным препаратам разных классов. Использовали химически синтезированные препарать (клопидол, декоквинат, галофугинон) и сочетания ионофорного антибиотика с синтетическим антикокцидийным препаратом (монензин+никарбазин, наразин+никарбазин). В качестве полевой культуры использовали смесь двух видов кокцидий, Eimeria acervulina и E. tenella, быделенную из биологических проб (подстилочный слой + помет) от разновозрастной птицы из хозяйства на территории Республики Беларусь. Размножение ооцист кокцидий и определение $L D_{50}$ проводили на 12-дневных иыплятах, сбободных от кокцидий. Оценку чувствительности изолята к препаратам исследовали на иьллятах 14-девного возраста, учитывали различия по приросту живой массы и летальность б опьтных и контрольных группах июллят; по этим критериям рассчитывали противококцидиозный индекс (ПКИ). Было установлено, что смесь полебых культур показала чубствительность к клопидолу. Значения ПКИ б группах с применением декокВината и комбинации монензин+никарбазин находились на границе чубствительности и частичной резистентности к эймериостатикам. За 10 дней наблюдения прирост живой массы 6 группах $c$ применением клопидола, монензина+никарбазина, декокъината пребышал 62 раза значение зараженной контрольной группы.
\end{abstract}

Ключебые слова: кокцидиоз, эймерии, антикокцидийные препараты, цьллята, E. tenella, E. acervulina.

Введение. Среди паразитарных болезней серьезную проблему для промышленного птицеводства представляют эймериозы. Основные экономические потери от этого заболевания приходятся на долю так называемого скрытого экономического ущерба, вызываемого латентной формой заболевания, при которой повреждается эпителиальный слой кишечника, что приводит к нарушению процессов пищеварения и всасывания питательных веществ, обезвоживанию организма, потере крови и повышенной чувствительности к другим возбудителям болезней.
Трудности борьбы с эймериозом, прежде всего, связаны с большим репродуктивным потенциалом паразита, устойчивостью кокцидий к дезинвазирующим препаратам и непродолжительностью приобретаемого иммунитета.

На протяжении 70 лет главным способом борьбы с кокцидиозом является использование эймериостатиков, которые препятствуют жизнедеятельности или полностью уничтожают паразита на разных этапах его эндогенного периода развития. Основной проблемой применения кокцидиостатиков является сравнительно быстрое формирование устойчивости паразита к препарату в относительно короткие сроки (за 4-5 лет), а также генетическая передача этих свойств последующим поколениям кокцидий.

В связи с этим необходимо постоянно проводить оценку адаптации кокцидий к используемым эймериостатикам, что позволяет более точно откорректировать схемы антиэймериозных программ, основанных на применении противококцидийных препаратов.

Стоит отметить, что до 1970 г. основной составляющей частью программ борьбы с кокцидиозом было использование кокцидиостатиков химического синтеза. 
Впервые о широком применении комбинированных препаратов в борьбе с кокцидиозом стали задумываться с появлением ионофорных антибиотиков [1].

Цель работы - определить уровень чувствительности полевого изолята эймерий к химически синтезированным и комплексным антикокцидийным препаратам.

материал и методика исследований. Материалом для данного исследования послужили биологические пробы (подстилочный слой + помет) от разновозрастной птицы, полученные из хозяйства на территории Республики Беларусь.

Получение ооцист кокцидий проводили методом Фюллеборна (флотация в насыщенном растворе хлорида натрия с фракционным центрифугированием). Видовой состав кокцидий определяли микроскопированием по биометрическим показателям и морфологическим свойствам ооцист с учетом места их локализации в кишечнике птицы.

Размножение ооцист кокцидий и определение $\mathrm{LD}_{50}$ проводили на 12-дневных цыплятах, свободных от кокцидий.

Оценкучувствительности полевого изолята кокцидий к препаратам определяли в опыте на 14дневных цыплятах, которых содержали в условиях, исключающих их естественное инвазирование кокцидиями. В опыте было задействовано 7 групп цыплят по 5 голов (2 контрольные и 5 подопытных). Цыплятам опытных и одной контрольной (зараженный

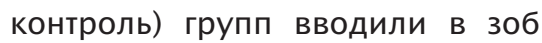
смесь полевого изолята в дозе $\mathrm{LD}_{50}$.

Цыплятам подопытных групп в течение 10 суток непрерывно, начиная за день до заражения, скармливали исследуемые препараты в смеси с комбикормом в дозах, утвержденных в наставлениях по их применению. Каждую группу цыплят взвешивали в начале опыта и по истечении 10 суток наблюдения, рассчитывали относительный (\%) и среднесуточный (г/гол./сут.) прирост живой массы.

Критерием антикокцидийной активности препарата служат различия в приростах живой массы и летальность в подопытных и контрольных группах цыплят. Оба этих показателя находят отражение в комплексном показателе противококцидиозном индексе (ПКИ), расчет которого проводят по формуле М.В. Крылова [2].

Для теста на чувствительность полевого изолята кокцидий к антикокцидийным препаратам использовали следующие группы эймериостатиков:

- химически синтезированные кокцидиостатики: клопидол (группа 3), декоквинат (группа 4), галофугинон (группа 5);

- комплексные или комбинированные кокцидиостатики, в состав которых входят химический кокцидиостатик и ионофорный антибиотик: монензин+никарбазин (группа 6) и наразин+никарбазин (группа 7).

Из-за широкого спектра действия химические кокцидиостатики влияют на различные биохимические процессы, отвечающие за жизнедеятельность паразита.

Клопидол (аналог пиримидинов) и декоквинат (производное хинолина) относятся к химическим кокцидиостатикам, которые ингибируют митохондриальную активность на ранних стадиях эндо- генного развития кокцидий [3].

Галофугинон (стенорол) принадлежит к новому классу химических антикокцидийных препаратов - производные алкалоидов. Изначально этот препарат был выделен из растения Dichroa febrifuga Lour. из сем. гортензиевых, которое используется для лечения малярии. Галофугинон действует на три последовательные стадии эндогенного цикла развития эймерий. Первое действие препарата проявляется при первой стадии заболевания - на спорозоитов; два других последовательных действия направлены на шизонты 1-й генерации и шизонты 2-й генерации [4].

Из-за развития резистентности кокцидий к эймериостатикам и снижения их сроков действия большое внимание было уделено разработкам комплексных антикокцидийных препаратов. Такие препараты состоят из действующих веществ, относящихся к различным химическим группам кокцидиостатиков и обладающие разными механизмами действия на паразита.

Механизм действия сочетания монензина (ионофорный антибиотик) и никарбазина (производное динитрокарбанилида) основан на образовании липидорастворимых комплексов с ионами $\mathrm{Na}^{+}$и $\mathrm{K}^{+}$, что нарушает осмотическое равновесие и параллельно тормозит энергетический метаболизм в клетке паразита, приводя к ее гибели [5].

Так как наразин и монензин состоят в одной подгруппе ионофорных антибиотиков - моновалентные ионофоры, то и принцип воздействия на эймерии комбинации наразин+никарбазин не отли- 


\begin{tabular}{|c|c|c|c|c|c|c|}
\hline Группа, препарат & $\begin{array}{l}\text { Кол-во } \\
\text { цыплят, } \\
\text { гол }\end{array}$ & $\begin{array}{c}\text { Пало, } \\
\text { гол }\end{array}$ & $\begin{array}{c}\text { Выжило, } \\
\%\end{array}$ & $\begin{array}{c}\text { Прирост } \\
\text { живой } \\
\text { массы, \% }\end{array}$ & $\begin{array}{c}\text { Среднесуточ- } \\
\text { ный прирост } \\
\text { живой массы, г }\end{array}$ & $\begin{array}{l}\text { ПкИ, } \\
\text { баллы }\end{array}$ \\
\hline 1. Контроль чистый & 5 & 0 & 100 & 112,1 & 52,0 & 200 \\
\hline 2. Контроль зараженный & 5 & 0 & 100 & 32,6 & 15,5 & 129 \\
\hline 3. Клопидол & 5 & 0 & 100 & 71,4 & 33,2 & 164 \\
\hline 4. Декоквинат & 5 & 0 & 100 & 66 & 31,2 & 159 \\
\hline 5. Галофугинон & 5 & 0 & 100 & 39,6 & 18,1 & 135 \\
\hline 6. Монензин+никарбазин & 5 & 0 & 100 & 64,7 & 30,4 & 158 \\
\hline 7. Наразин+никарбазин & 5 & 0 & 100 & 55,5 & 26,4 & 150 \\
\hline
\end{tabular}

чается от сочетания монензин+никарбазин.

\section{Результаты исследований и} их обсуждение. Из полученных проб был выделен полевой изолят, представленный двумя видами кокцидий: Eimeria acervulina и E. tenella.

При определении вирулентности смеси полевых изолятов кокцидий на 12-дневных цыплятах было установлено, что гибель цыплят от кокцидиоза начинается с дозы более 2,5 млн. спорулированных ооцист при пероральном заражении цыплят 12-дневного возраста.

В течение 10 суток опыта по сравнительному изучению различных препаратов на 14 дневных цыплятах гибели цыплят в опытных и контрольных группах не наблюдалось. Показатели для оценки чувствительности смеси полевых изолятов кокцидий к противококцидийным препаратам представлены в табл. 1 .

ПКИ в опытных группах колебался от 135 баллов (группа гало- фугинона) до 164 баллов (группа клопидола). Смесь полевых культур E. acervulina и E. tenella показала чувствительность к клопидолу. Ко всем остальным исследованным препаратам установлена частичная резистентность.

Значения ПКИ в группах с декоквинатом и комбинацией монензин+никарбазин находились на границе чувствительности и частичной резистентности к эймериостатикам, а прирост живой массы превышал значение в группе зараженного контроля в 2 раза.

Заключение. Анализ результатов исследования показал, что препараты по их активности против выделенной смеси полевых культур можно разделить на три группы:

1. Активные препараты - клопидол;

2. Препараты средней активности - декоквинат, монензин+накарбазин;

3. Препараты риска - галофугинон, наразин+накарбазин.
Препараты средней активности, наряду с клопидолом, можно включать в ротационную программу при строгом контроле возникновения и распространения эймериоза в хозяйстве.

Препараты риска следует исключить из ротационной программы для восстановления чувствительности к ним полевых культур кокцидий.

\section{Литература}

1. Kadykalo S., Roberts T., Thompson M., Wilson J., Lang M., Espeisse O. The value of anticoccidials for sustainable global poultry production // Intl. J. Antimicrob. Agents. - 2018. - V. 51. - P. 304-310.

2. Крылов М.В. Оценка кокцидиостатических свойств препаратов // Ветеринария. - 1969. - №1 0. - С. 48-51.

3. Noack S., Chapman H.D., Selzer P.M. Anticoccidial drugs of the livestock industry // Parasitol. Res.- 2019. - V. 118 , No 7. - P. 2009-2026.

4. Хованских А.Е. Кокцидиоз сельскохозяйственной птицы /А.Е. Хованских, Ю.П. Илюшечкин, А.И. Кириллов. - Л.: Агропромиздат, 1990. - С. 150.

5. Kant V., Singh P., Verma P.K., Bais I., Parmar M.S., Gopal A., Gupta V. Anticoccidial drugs used in the poultry: an overview // Sci. Intl. - 2013. - V. 1, No 7. - P. 261-265.

Для контакта с авторами:

Бирюков Илья Михайлович

E-mail: i_biryukov88@mail.ru

Симонова Екатерина Александровна

E-mail: vetsaneco.vnivip@yandex.ru

\section{The Assessment of the Sensitivity of a Coccidial Field Isolate to the Synthetic and Combined Coccidiostatics}

Biryukov I.M., Simonova E.A.

Federal Scientific Center "All-Russian Research and Technological Institute of Poultry" of Russian Academy of 